\title{
Acquired Factor XI Deficiency
}

National Cancer Institute

\section{Source}

National Cancer Institute. Acquired Factor XI Deficiency. NCI Thesaurus. Code C131627.

An acquired coagulation disorder characterized by the partial or complete absence of factor XI activity in the blood. 